Technological University Dublin

DÜBLIN

ARROW@TU Dublin

2014

\title{
CEO Pay Slice and Firm Value: Evidence from UK Panel Data
}

Valentina Tarkovska

Technological University Dublin, valentina.tarkovska@tudublin.ie

Follow this and additional works at: https://arrow.tudublin.ie/busaccoth

Part of the Accounting Commons

\section{Recommended Citation}

Tarkovska, V. (2014) CEO Pay Slice and Firm Value: Evidence from UK Panel Data. Working paper published by Dublin Institute of Technology 2014.

This Working Paper is brought to you for free and open access by the School of Accounting and Finance at ARROW@TU Dublin. It has been accepted for inclusion in Other resources by an authorized administrator of ARROW@TU Dublin. For more information, please contact arrow.admin@tudublin.ie, aisling.coyne@tudublin.ie,gerard.connolly@tudublin.ie. 
Dublin Institute of Technology

ARROW@DIT

Articles

School of Accounting and Finance

2014

\section{CEO Pay Slice and Firm Value: Evidence from UK Panel Data}

Valentina Tarkovska

Follow this and additional works at: http://arrow.dit.ie/buschacart

Part of the Accounting Commons

This Article is brought to you for free and open access by the School of

Accounting and Finance at ARROW@DIT. It has been accepted for inclusion in Articles by an authorized administrator of ARROW@DIT. For

more information, please contact yvonne.desmond@dit.ie,

arrow.admin@dit.ie.

Creative Commons License

This work is licensed under a Creative Commons Attribution-

Noncommercial-Share Alike 3.0 License 


\title{
CEO Pay Slice and Firm Value: Evidence from UK Panel Data \\ Valentina Tarkovska \\ School of Accounting and Finance, Dublin Institute of Technology, Ireland \\ email:valentina.tarkovska@dit.ie
}

\begin{abstract}
This study examines a relationship between the CEO Pay Slice (CPS) - the fraction of the top five executive directors' total compensation that is captured by CEO - and firm value in the UK. CPS reflects the relative importance of CEO as well as the extent to which the CEO is able to extract rents. CPS may also alter effectiveness of board performance by influencing cooperation and cohesiveness among its members. Using a large sample of UK-listed companies over the 1997 to 2010 period, we document evidence supporting a negative relationship between CPS and firm value as measured by Tobin's Q. Our results are consistent with the hypothesis that high CPS is associated with agency problems, and is likely to impact negatively on the executive team's spirit and motivation. Our results have major implications for the on-going debate on how to reform executive remuneration, and highlight the importance of considering remuneration issues at the board level, supporting the principles of UK Corporate Governance Code (2010).
\end{abstract}

JEL classification: G32, G35, G38, J33, L29

Key words: executive compensation, CEO compensation, corporate governance, agency problem, firm performance. 


\section{Introduction}

Corporate scandals about 'fat cats' compensation packages in Britain[1] are a timely reminder that pay-performance problem in the UK requires further attention. Shortcomings in regulation of compensation-related issues have been addressed by the UK Corporate Governance Code 2010 (The Code), with the particular attention being paid to the importance of establishing definite connections between director's remuneration and firm performance[2]. In September 2013, the UK Government also introduced a mandatory "say on pay" legislation allowing firm's shareholders to vote on the remuneration of executives.

In this study, we aim to shed additional light on the link between executives' compensation and a firm performance in the UK context. In particular, we investigate whether pay inequality between CEO and top executives affects performance of British companies. We hypothesize that fraction of aggregate compensation of top-five managers captured by the CEO personally (the CPS) impacts board effectiveness, which in turn affects firm outcomes. In our analysis, we controls for several corporate governance characteristics (board composition, board size, CEO duality, CEO tenure, and board busyness) and for various firm characteristics (company age, company size, ratio of capital expenditures to total assets, and leverage). We use a large sample of non-financial companies listed on the London Stock Exchange, comprising 1,401 firms and 6,959 firm-year observations over the 1997 to 2010 time period. Our empirical methodology includes estimation of panel data by using various fixed effects models.

i. See The Guardian: "David Cameron to curb 'fat cat' pay with people power"', $7^{\text {th }}$ January, 2012 , available at http://www.theguardian.com/business/2012/jan/07/david-cameron-fat-cat-pay. "We've got to deal with the merry-go-round where there are too many cases of remuneration committee members sitting on each other's boards, patting each other's backs and handing out each other's pay rises," he said. "We need to redefine the word 'fair'. We need to try to give people a sense that we have a vision at the end of this, of a fairer, better economy, a fairer, better society, where if you work hard and do the right thing you get rewarded"

ii. Section D: Remuneration. Main Principle: "levels of remuneration should be sufficient to attract, retain, and motivate directors of the quality required to run the company successfully, but a company should avoid paying more than is necessary for this purpose. A significant proportion of executive directors' remuneration should be structured so as to link rewards to corporate and individual performance." (The UK Corporate Governance Code, June 2010: p.22). 
We find consistent support for the proposition that higher CPS is associated with lower firm value as measured by Tobin's Q. Our results rule out the optimal contracting hypothesis, which suggests that high CPS is determined deliberately by a company as the motivation incentive (to motivate CEO as well as top executive directors) with the view to improve firm outcomes. However, the results strongly support the agency perspective, suggesting that high CPS level could be due to the agency problem in firm with powerful and influential CEO. In addition, high CPS could demotivate those managers nearest to the CEO, destroy team cooperation within the board room, and lead to poor board and thus firm performance (via the social comparison effect, inherent to British boards[3]). Our results indicate that CPS can provide a useful tool for research on firm performance, and that its relation with the value of firms is an important issue to be considered in the UK context.

Our study relates to different bodies of literature. First, there is clear evidence from the literature that proportion of compensation received by CEO has been trending up over time (see Bebchuk and Grinstein, 2005; Frydman, 2005; Frydman and Saks, 2010; Forbes et al., 2014 among others). We add to this stream by investigating the relationship between CPS and firm performance in the UK context. Second, we extend the literature analysing the association between different corporate governance characteristics and Tobin's Q (see Yermack, 1996; Bebchuk and Cohen, 2005; Gompers et al., 2003; Bebchuk et al., 2009 among others). We contribute to this literature by considering another aspect of governance arrangements, the CPS, and its impact on firm performance. Finally, our work enhances the literature that analyses different CEO qualities and characteristics and their effects on firm outcomes. We highlight CPS as an important feature, which can provide additional insights into understanding of CEO compensation - firm performance link.

The reminder of the paper is organised as follows. We provide a theoretical background

iii. See Zalewska (2014a,b) for detailed discussion of the UK board mechanisms and structures. 
and develop our hypotheses in Section 2. Section 3 contains the sample description and summary statistics. Section 4 outlines the methodology used for the analysis. Section 5 examines the relationship between CPS and firm value. Section 6 concludes.

\section{Theoretical Background and Hypothesis Development}

\subsection{Remuneration Disparity and Firm Performance}

Academic literature suggests that pay difference within top management has important consequences for functional efficiency of the management team and, subsequently, on firm performance (see Bebchuk and Grinstein, 2005; Murphy and Zabojnik, 2007; Lee et al., 2008; Fredrickson et al., 2010; Fridman and Saks, 2010; Bebchuk et al., 2011; Zalewska, 2014a; Forbes et al, 2014 among others). Even though researchers confirm existence of the relationship between pay inequality and firm performance, there is a disagreement regarding the nature of this relationship. Lazer and Roshen (1981), Rosen (1986), Eriksson (1999), Henderson and Fredrickson (2001), DeVaro (2006a, 2006b), Lee et al. (2008), Kale et al. (2009), Rankin and Sayre (2011) find that pay disparity has a positive effect on company performance. On the other side, Hayward and Hambrick (1997), Bloom and Michel (2002), Carpenter and Sanders (2002), Siegel and Hambrick (2005), Fredrickson et al. (2010), Bebchuk et al. (2011), Zalewska (2014a), report that a wide remuneration gap among executives affects firm outcomes in a negative way.

Despite the growing body of literature on executives' remuneration disparity, there are only a handful of studies examining its effect on firm performance using UK data. Correa and Lel (2014) investigate the effect of "say on pay" law on executive compensation, CPS and firm value using a large cross-country sample from 39 countries including the UK. They find that CEO pay - firm performance links become stronger when "say on pay" laws are implemented, and that companies that previously had greater CPS, experience significant performance improvements. These findings imply a negative correlation between CPS and 
firm outcomes, and are consistent with results from previous research (e.g., Bebchuk et al., 2011). Zalewska (2014a) analyses the link between remuneration dispersion at executive board level and firm performance using a large sample of British companies. She also unveils a negative relationship between remuneration dispersion and performance. Forbes et al. (2014) criticise CPS as a valuable measure to be used in the analyses of pay disparity corporate performance relationship, and introduces a Gini coefficient as an alternative.

\subsection{Optimal Contracting}

Under the optimal contracting theory, CEO compensation is determined by a complex set of factors and reflects CEO talent, ability, experience, and career concerns. Optimal compensation reflects the extent to which companies are willing to offer 'tournament' incentives to top executives other than a CEO. Optimal contracting arguments (See Edmans and Gabaix, 2011 for review) suggest that high CEO pay - relative to pay of other top executives - is determined deliberately by companies as motivation incentive with the view to improve firm outcomes. In a typical rank order tournament framework, the best performer is promoted to the next level in the managerial hierarchy. The promotion guarantees a higher pay level, so the framework motivates executive directors to exert greater efforts and perform better. Earlier empirical research on labour economics (e.g., Bognanno, 2001), and the most recent research on corporate finance (e.g., Kale et al. , 2009) use the compensation gap between $\mathrm{CEO}$ and lower-rung executives as a measure of tournament incentives. Lee et al. (2008) and Kale et al. (2009), among others, find tournament incentives to be an important mechanism in motivating managers.

Based on the above, we hypothesize that companies intentionally decide to set high CPSs to motivate their CEOs and top executives other than CEOs. CEO is motivated to be a good steward and make every effort to ensure successful company performance, because he/she 
takes care about his/her own reputation (Gibbons and Murphy, 1992); in turn, top executives, other than $\mathrm{CEO}$, are also motivated to perform better while competing for the CEO position. This leads us to the following hypothesis:

Hypothesis 1: CPS is positively associated with firm value.

\subsection{Social Comparison Perspective}

In contrast to the optimal contracting theory, there is a very strong opposing view on the effects that high remuneration disparity has on a firm value. Fong et al. (2010) argue that compensation should reflect a manager's ability, but at the same time should not lay the foundation for strong feelings of inequality/injustice among peers on the labour market. Milgrom and Roberts (1992) demonstrate that tournament mechanisms within the executive team can produce negative incentives for top executives other than CEO. It is very unlikely that a company will benefit from the tournament framework if top executives who are competing for the $\mathrm{CEO}$ position refuse to cooperate and even might undermine their rivals. A wide gap between CEO compensation and compensation of top executives (the "prize size") emphasises on the importance of the CEO as a "dominant player" (Bebchuk et al., 2011). Bebchuk et al. (2011) argues that it is beneficial to have a dominant player as he/she can guarantee clarity, steadiness and cost reduction of decision making process. On the other side, a large body of literature, starting with Shaw (1932), suggests that group decision making is superior to the individual decision making. Moreover, the dominant player approach can lead to resentment on the part of other members of the top executive team (Brill, 1993; Cook, 1990). Hicks (1963) introduced the notion that large pay differences may have a negative impact on employees through feelings of inequity and it may lead to a weaker employees' dedication increasing a dysfunctional conflict, which, in turn, "diminish the efficiency of the team" (Hicks, 1963: p. 334). Akerlof and Yellen (1988, 1990), Milgrom and Roberts (1988) 
and Levine (1991) build up on the earlier work of Hicks (1963) and argue that low pay differences may have positive effect on employees' diligence and productiveness by creating well-balanced and efficient labour relations leading thereby to better outputs. Levine (1991) also demonstrates that lower level of pay dispersion leads into better employee cohesiveness and productivity[4]. Considering that UK boards are not strongly hierarchical and CEOs are not so powerful in Britain compared to their American colleagues (see Tom and Wright, 2005; Aguilera et al., 2006), high CPS can impact negatively on team spirit and motivation, weakening board effectiveness. In accordance with the social comparison view[5], this can attenuate firm performance.

High level of CPS also can be viewed as a sign of significant agency problems. CPS can indicate the extent to which a CEO uses his/her power and influence to serve his/her own interests (Bebchuk et al., 2011), captures a board and set up his/her own pay (Bebchuk and Fried, 2004). Bebchuk et al. (2011) find that CEO pay slice (CPS) negatively affects firm performance, especially in firms with entrenched managers.

Based on the above, we argue that CEO may be able to entrench, maximise his/her own power, and extract rents by securing higher than optimal compensation, regardless of his/her quality of service. A high CPS level may result in lower cohesion and less cooperation among board members, which negatively affects firm performance. This leads us to the following hypothesis:

Hypothesis 2: CPS is negatively associated with firm value.

\section{Sample Selection and Data Description}

\subsection{Sample Selection}

iv. This argument is also consistent with research on cooperation in general economic situation (Milgrom and Roberts, 1988; Lazear, 1989; van den Assem et al., 2012).

v. The social comparison theory was introduced by Festinger (1957), and underlines equity theory oriented concerns (Adams, 1965). 
For this study, we use a large sample of non-financial companies listed on the London Stock Exchange. We obtain firms' financial and market information from Thompson Datastream, and corporate governance and directors' compensation information from BoardEx. The sample period is from 1997 to 2010, and it includes all firms whose information is available from these two sources. The choice of year 1997 as the start year for our sample window is due to the limited availability of corporate governance data prior to this year.

We merged the data from BoardEx and Thomson Datastream and ended up with unbalanced panel of 1,401 firms and 6,959 observations over the 1997 - 2010 time period. Our definition of CPS is marginally different from definition in Bebchuk et al. (2011). British corporate boards are, on average smaller than American boards. Only $16 \%$ of our sample companies have five or more executive directors at the board level. We compute CPS as the fraction of the total compensation paid to a group of minimum two and maximum five top executives, that is received by the CEO. We use Tobin's Q as a key measure of corporate performance. We control for other potential determinants of firm value, found to be important in the previous studies (see Bebchuk et al., 2011; McNulty et.al., 2013; Zalewska, 2014a; Forbes et al., 2014) and include firm size, company age, capital expenditures, and leverage in our model. We also collect information about the governance structure of each firm, such as board size, board composition, board busyness, CEO tenure, CEO duality, whether the CEO is insider or outsider, i.e. was/was not an employee of the firm before his/her appointment to the CEO position, and information on the compensation of executive directors other than CEO. All variable definitions are provided in Table 1. Tables 2 and 3 give sample calculation examples for Board Busyness and CPS respectively.

*****Insert Tables $1,2 \& 3$ here $* * * * *$

\subsection{Data description and summary statistics}


We report summary statistics in Table 4[6]. We separate data into variables describing firm performance (Panel A); compensation, director characteristics and board structure (Panel B); and other firm characteristics (Panel C). The average CEO pay slice (CPS) based on the total compensation of up to top five executives including CEO is $45.22 \%$, with minimum 0 and maximum $100 \%$. The boards in our sample have on average 7 directors with minimum 3 directors and maximum 14 directors. The average proportion of executive directors at the board level (Board Composition) is $48.44 \%$ with minimum of $13.51 \%$ and maximum $80 \%$ of executives at the board. The average CEO tenure is 4.44 years in our sample companies, with minimum 0 and maximum 24.70 years. $57.81 \%$ of companies in our sample have CEOs, who were not employees of the company before (Outside CEO).

Firm size is, on average 4.35 . The leverage level is $17.70 \%$ in the average company, with maximum leverage standing at $95 \%$, and minimum leverage equals to $0 \%$. Company age is, on average, 13.78 years, with the oldest company being in existence for 45 years, and the youngest company in our sample being just 0.34 years old. The maximum (minimum) ratio of capital expenditures to total assets is $0.34(0)$, with the average being 0.05 . The average Tobin's $\mathrm{Q}$ is 2.55 , with maximum (minimum) Q equals to 20 (1.50).

$* * * * * * *$ Insert Table 4 here $* * * * * * *$

Table 5 reports CPS descriptive statistics. The statistics are presented for each year separately, along with statistics for two sub-samples, before and after year 2002[7]. On average, CPS has been growing over the 1997-2010 period. This is consistent with the evidence from the literature that proportion of compensation received by CEO has been on an upwards trend over time (see Bebchuk and Grinstein, 2005; Frydman, 2005; Frydman and

vi. All variables are winzorized to the 1st/99th percentiles.

vii. In 2002, the UK was the forerunner in mandating that shareholders be allowed a non-binding, or advisory vote on executives' pay ("say on pay"). 
Saks, 2010). Introduction of advisory "say on pay" law in 2002 has not changed this increasing trend. In particular, mean CPS has been increasing gradually, from $32 \%$ in the year 1997 to $50 \%$ in year 2010, with an average CPS around $40 \%$ before the introduction of "say on pay", i.e. before 2002, and average CPS around 47\% upon implementation of this law, i.e. from year 2003 onwards. This is in agreement with results in Ferri and Maber (2013) who find that introduction of "say on pay" has a limited effect on the levels of CEO compensation.

$* * * * *$ Insert Table 5 here $* * * * *$

\section{Methodology}

In this section, we examine the effect of CPS on company performance. We follow the literature that relates firm performance to various corporate governance characteristics and use Tobin's Q as a measure of firm performance (see Demsetz and Lehn, 1985; Morck, Shleifer, and Vishny, 1988; Lang and Stulz, 1994; Gompers et al., 2003). The CPS definition is adopted from Bebchuk et al. (2011) with a minor modification, which was necessary due to the difference in board sizes in the UK and US[8].

We include control variables that have been considered important in the previous literature (see Bebchuk et al., 2011; McNulty et al., 2013; Zalewska, 2014a). We include Board Composition, which is a proportion of executive directors at the board level. Considering the nature of data available and difficulties with identifying independent directors, we use Board Composition measure as a proxy for board independence (a lower proportion of executive directors at the board level is associated with higher level of board independence). Previous academic research finds board independence important in designing

viii. See Section 3.1 for the definition of CPS. 
a CEO compensation plan (see Mehran, 1995; Ozerturk, 2005). We also control for board size and include natural logarithm of a total number of directors at the board level (Board Size). Academics provide controversial evidence on the relation between board size and company performance, with some documenting positive (Pearce and Zahra, 1992; Dalton et al., 1998; Jackling and Johl, 2009), while others reporting negative association (Yermack, 1996; Van den Berghe and Levrau, 2004). In addition, we control for board busyness and include Busy Board variable, defined as a proportion of busy directors (directors with three or more directorships) at the board level. Core et al., (1999), and Shivdasani and Yermack (1999) suggest that directors can become overcommitted when serving on multiple boards, rendering them unable to provide meaningful managerial monitoring. Fich and Shivdasani (2006), Jiraporn et al. (2006), and Jiraporn et al. (2008) argue that boards with busy directors are associated with lax corporate governance and lower firm value. We also include a variable indicating that $\mathrm{CEO}$ and Chairman is the same person (Duality). We consider CEO Tenure as explanatory variable in our models. Bebchuk et al. (2011) suggest that CEO tenure impacts on firm performance, Hermalin and Weisbach (1998) argue that CEO propensity to employ more allies to the board will increase with his/her tenure, thereby increasing the CEO bargaining power. In line with Bebchuk et al. (2011), and Murphy and Zabojnik (2007) we also consider a CEO outsider variable. Murphy and Zabojnik (2007) document that CEOoutsider receives higher compensation resulting in higher level of CPS, which could be an indication of his/her unique skills and not necessarily agency problems.

It is important to recognise that CPS could be endogenously determined, i.e. affected by the factors that are also affect firm performance. To account for this, we use fixed effects models, which consider how changes in CPS are associated with changes in firm value (Model 1)

$$
\text { Performance }_{l t}=\beta_{0}+\beta_{1} \widetilde{\text { PSS }_{l t}}+\beta_{2} \text { CEO } \widetilde{\text { Tenure }}_{l t}+\beta_{3} \text { CEO } \widetilde{\text { Outslder }}{ }_{l t}+\beta_{4} \text { Duallt }_{l t}+
$$




$$
\begin{aligned}
& \beta_{5} \text { Board Composition }{ }_{l t}+\beta_{6} \text { Company Size }+\beta_{7} \text { Company Age } e_{l t}+\beta_{8} \widetilde{\operatorname{Capex}}_{l t}+ \\
& \beta_{9} \text { Leverag }_{l t}+\beta_{10} \text { Busy_Board }_{l t}++\sum_{j=2}^{13} \beta_{j} \text { YearDumm }_{t}+\varepsilon_{i t}
\end{aligned}
$$

where the $\sim$ (tilde) defines demeaned variables, and Performance $_{i t}$ is our performance measure, i.e. Tobin's Q. All other variable definitions are in Table 1.

We ran fixed effects models with robust standard errors and robust standard errors clustered by industry. We also use fixed effect models with Driscoll-Kraay (1998) standard errors, which are robust to general forms of cross-sectional and temporal dependence. We also use industry-adjusted CPS in each firm's industry at the same FTAG3 level in the same year. In addition, we examine whether our results are robust to alternative specification of CPS based on the total compensation of a maximum of three (rather than five) executive directors (CPS 3 directors).

\section{Results}

\subsection{Univariate analysis}

Table 6 presents univariate comparison of key descriptive variables by CPS quartiles. Firms with high CPS appear to differ significantly from those with low CPS. Tobin's Q declines as CPS increases. It declines in the second and third quartiles (as predicted by the agency and social comparison arguments) and then increases in the fourth quartile again. The firms with highest CPS are smaller than those with the lowest CPS. Firms in the first quartile of CPS are younger than the firms in the fourth quartile. The univariate relation between CPS and Capex is not monotonic. Firms in the first three CPS quartiles have similar Capex, but firms in the fourth quartile have lower Capex. Leverage increases from the first to the fourth quartile of CPS. Firms with highest CPS have the busiest boards. Board size declines monotonically from the first to the fourth quartile of CPS. Board composition changes in line with the board size and declining monotonically from the first to the fourth quartile, which is consistent with 
the view that CEO can entrench himself/herself, extract rents and increase agency costs, if board is less independent. Proportion of 'outside' CEOs increases gradually from the first to the fourth quartile suggesting that such directors are more valuable assets for companies.

*********Insert Table 6 here $* * * * * * *$

\subsection{Multivariate analysis}

In this section we discuss our empirical results concerning the association between CPS and firm value measured by Tobin's Q. The regression results are reported in Table 7. We separately report estimation results using fixed effects models with White (Panel A), robust clustered by industry (Panel B), and Driscoll-Kraay (1988) (Panel C) standard errors correction methods. Our main model is Model 1, with Tobin's Q being regressed against CPS and our selected firm and governance control variables. We find that CPS coefficients are negative and significant (at the $1 \%$ level in Panel A and Panel B, and at the $10 \%$ in Panel C). In terms of economic significance, one standard deviation change in CPS is associated with a reduction in Tobin's Q by $11.91 \%$.

We consider industry-adjusted CPS[9] (Model 2) and CPS computed using total compensation of maximum three executive directors (Model 3). The results remain robust to these alternative specifications with negative and statistically significant CPS coefficients. These results are consistent with the view that high CPS adversely affects firm performance, supporting social comparison argument and Hypothesis 2. Our results are in line with results reported in the literature starting with Hicks (1963), who introduced the notion that large pay disparity may have a negative impact on employees through feeling of inequality and leads to a weaker dedication, diminishing efficiency of a team. Our results are in agreement with

ix. The industry adjustment is made by subtracting industry mean CPS (at the same FTAG3 level) from firm CPS in the same year 
findings in Bebchuk et al. (2011), Correa and Lel (2014), and Zalewska (2014a), who argue that a wide remuneration gap among executives affects firm outcomes in a negative way. Throughout our analysis we were not able to find support for the optimal selection argument (Hypothesis 1). Considering that UK boards are not strongly hierarchical (see Zalewska, 2014a, 2014b), our results suggest that "tournament incentives" are ineffective in British companies.

Examining control variables in the regressions, we find some interesting results. One of our corporate governance characteristics, Board size, has coefficients that are negative and statistically significant (at the $1 \%$ level), supporting the view that small boards are more efficient and perform better than their large counterparts when it comes to managing company performance. Both company size and capital expenditure coefficients are positive and statistically significant (at the 1\% level), suggesting that bigger companies and those with higher capital expenditure levels perform better. We also find positive relationship between leverage and Tobin's Q. These findings are in line with findings in previous literature (see Bebchuk et al , 2011; McNulty et al., 2013; Zalewska, 2014a).

*********insert Table 7 here $* * * * * * *$

\section{Conclusion}

In this paper, we investigate how CPS, the proportion of maximum top-five executive directors' aggregate compensation captured by CEO, affects firm performance. We offer new insights into the pay inequality - performance relationship by evaluating three different arguments that are prevalent in the finance and management literature. One view claims that high CPS level distinguishes a company's CEO and helps to create a good competition spirit within the board room resulting in better corporate performance. However, two other views 
suggest exactly opposite: high CPS can be an indicator of agency problems in a company in which a powerful CEO extracts unjustified rents (agency argument), and could harm board effectiveness by impairing team cohesiveness and motivation (social comparison argument), in either case resulting in poor corporate performance

Our analysis reveals a negative association between CPS and corporate performance measured by Tobin's Q. This evidence supports both the agency and social comparison arguments. The results of our study are robust for controlling for various firm, board and CEO characteristics. Our results are also robust to the different specifications of CPS. Our findings are in line with Bebchuk et al. (2011) and Correa and Lel (2014). However, this is the one of the first studies that we are aware of, which investigates the CPS - performance relationship using the broad sample of UK-based companies[10]. We find that results from the UK sample are similar to those from studies on US companies. However, the underlying reason for the negative relationship between CPS and firm performance could differ between the UK and US contexts. Considering the specificity of UK corporate boards (see Zalewska, 2014a,b), it is natural to put forward the social comparison argument as an important reason for the negative associations between CPS and firm performance[11].

Given the changes in remuneration practices introduced by the UK Corporate Governance Code (2010) and the "say on pay" legislation (2013), we argue that CPS is an important aspect of firm governance and management that deserves attention of researchers and policy makers. The fact that high CPS negatively impacts on firm performance has strong implications for the on-going debate on how to reform executive remuneration so that it

\footnotetext{
x. Forbes, Pogue and Hodgkinson (2014) use smaller sample of companies, considering firms from the UK FTSE 100 index in their study of CPS-performance relationship.

xi. UK companies are generally characterised by high corporate governance standards, but agency problems may still exist in some companies. However, considering the attention the business community has given to the issue, and the recommendations provided by the most recent UK Corporate Governance Code (2010), it is natural to assume that agency conflicts would be minimal, and that the social comparison argument is more likely to explain the negative CPS - performance relationship.
} 
provides the right incentives. It highlights the importance of considering remuneration issues at the board rather than at the CEO or at the sectoral or industry levels, and supports the UK Corporate Governance Code (2010) principles[12]. UK corporate governance reforms move towards increasing board's responsibilities for company's performance, and it is important to consider board-wide remuneration issues without narrowing them down simply to the details of CEO compensation.

xii. "The performance-related elements of executive remuneration... should be sensitive to pay and employment conditions elsewhere in the group" (Supporting principle, Section D: Remuneration, The UK Corporate Governance Code, 2010: p. 22). 


\section{References}

Adams, J.S. (1965), “Inequity in social exchange.” In L. Berkowitz (Ed.),Advances in experimental social psychology (Academic Press) Vol.2, pp. 267-299.

Aguilera, R., Williams, C., Conley, J., Rupp D.(2006), "Corporate Governance and Social Responsibility: a comparative analysis of the UK and the US." Corporate Governance: An International Review Vol. 14, no. 3 pp. 147-158.

Akerlof, G., Yellen, J. (1988) ,"Fairness and Unemployment.” American Economic Review Vol. 78, no. 2, pp. 44-49.

Akerlof, G., Yellen, J. (1990) , “The Fair Wage-Effort Hypothesis and Unemployment.” The Quarterly Journal of Economics, Vol. 105, no. 2, pp. 255-283.

Bebchuk L., Fried, J. (2003) ,"Executive Compensation as an Agency Problem.” Journal of Economic Perspectives, Vol.17, no. 3, pp. 71-92.

Bebchuk L., Fried, J. (2004), “Stealth Compensation Via Retirement Benefits.” NBER Working Papers 10742 (National Bureau of Economic Research, Inc. )

Bebchuk, L., Cohen, A. (2005), "The Costs of Enternched Boards.” Journal of Financial Economics, Vol. 78, pp. 409-433.

Bebchuk, L., Cohen, A., Ferrell, A. (2009), “What matters in corporate governance?” Review of Financial Studies Vol. 22, pp. 783-827.

Bebchuk, L., Cremers, M., Peyer, U. (2011), “The CEO pay slice.” Journal of Financial Economics, Vol.102, pp. 199-221.

Bebchuk, L., Grinstein, Y. (2005), "The Growth of Executive Pay." Oxford Review of Economic Policy, Vol. 21, no. 2, pp. 283-303.

Bloom, M., Michel, J. (2002), "The relationships among organizational context, pay dispersion, and managerial turnover." Academy of Management Journal , Vol. 45, pp. $33-42$.

Bognano, M. (2001), “Corporate tournaments.” Journal of Labour Economics, Vol.19, no. 2, pp. 290-315.

Carpenter, M., Sanders, W. (2002), “Top management team compensation: The missing link between CEO pay and firm performance?" Strategic Management Journal, Vol.23, pp. 367-375.

Cook, F., W. (1990), "How much stock should management own." Compensation and Benefits Review, September- October, pp. 20-28.

Core, J., Holthausen, R., Larcker, D. (1999), "Corporate governance, chief executive officercompensation, and firm performance." Journal of Financial Economics, Vol. 51, pp. 371-406.

Correa, R., Lel, U. (2014), "Say on Pay Laws, Executive Compensation, Pay Slice, and Firm Value around the World." working paper, The Federal Reserve Board, March . 
Dalton, D., Daily, C., Ellstrand, A., Johnson, J. (1998), "Meta-analytic reviews of board composition, leadership structure, and financial performance." Strategic Management Journal, Vol. 19, pp. 269-290.

Demsetz, D., Lehn, K. (1985), "The structure of corporate ownership: causes and consequences.” Journal of Political Economy, Vol. 93, pp. 1155-1177.

DeVaro, J. (2006a) "Internal promotion competition in firms." RAND Journal of Economics, Vol.37, no. 3, pp. 521-542.

DeVaro, J. (2006b), “Strategic promotion tournaments and worker performance." Strategic Management Journal, Vol.27, pp. 721-740.

Driscoll, J., Kraay, A. (1998), "Consistent covariance matrix estimation with spatially dependent panel data." The Review of Economics and Statistics, Vol.80, no. 4, pp. 549-560.

Edmans, A., Gabaix,X. (2011), "Tractability in incentive contracting." Review of Financial Studies, Vol. 102, no. 1, pp. 81-101.

Eriksson, T. (1999), "Executive compensation and tournament theory: empirical tests on Danish data." Journal of Labor Economics, Vol.17, no. 2, pp. 262-280.

Ferri, F., Maber, M. (2013), "Say on pay votes and CEO compensation: evidence from the UK." Review of Finance, Vol.17, pp. 527-563.

Festinger, L. (1957), A Theory of Cognitive Dissonance. Row, Peterson: Evanston, III.

Fich, E., Shivdasani, A. (2006), “Are busy boards effective monitors?” Journal of Finance, Vol. 61, pp. 689-724.

Fong, E., Misangyi, V., Tosi, H. (2010), "The effect of CEO pay deviations on CEO withdrawal, firm size, and firm profits.” Strategic Management Journal, Vol. 31, pp. 629-651.

Forbes, W., Pogue, M., Hodgkinson, L. (2014), "CEO pay in UK FTSE 100: Pay inequality, board size and performace." The European Journal of Finance, forthcoming, DOI:10.1080/1351847X.2014885457.

Fredrickson, J.,Davis-Blake, A., Sanders, G. (2010), "Sharing the Wealth: Social Comparisons and Pay Dispersion in the CEO's Top Team." Strategic Management Journal, Vol.31, no. 10, pp. 1031-1053.

Frydman, C. (2005), "Raising through the ranks: the evolution of the market for corporate executives.” working paper, MIT Sloan School of Management, pp.1936-2003.

Frydman, C., Saks, R. (2010), "Executive compensation: a new view from long-run perspective.” Review of Financial Studies, Vol.23, pp. 2099-2138.

Gibbons, R. and Murphy, K., (1992), "Optimal Incentive Contracts in the Presence of Career Concerns: Theory and Evidence.” Journal of Political Economy, Vol.100, no. 3, pp. 468-505. 
Gompers, P., Ishii, J., Metrick, A. (2003) , "Corporate governance and equity prices." Quarterly Journal of Economics, Vol. 118, no. 1, pp. 107-155.

Hayward, M., Hambrick, D. (1997), "Explaining the premiums paid for large acquisitions: Evidence of CEO hubris." Administrative Science Quarterly, Vol. 42, pp.103-127.

Henderson, A., Fredrickson, J. (2001), "The management team coordination needs and the CEO pay gap: A competitive test of economic and behavioral views." The Academy of Management Journal, Vol. 44, pp.1996-117.

Hermalin, B., Weisbach, M. (1998), "Endogenously chosen boards of directors and their monitoring of the CEO" American Economic Review, Vol.88, no. 1, pp. 96-118.

Hicks, J.R. (1963), The Theory of Wages. London: Macmillan.

Jackling, B., Johl, S. (2009), "Board structure and firm performance: Evidence from India's top companies." Corporate Governance: An International Review, Vol.17, no. 4, pp. 492-509.

Jiraporn P., Miller,G., Yoon, S., Kim, Y. (2008), "Is earnings management opportunistic or beneficial? An agency theory perspective." International Review of Financial Analysis, Vol.17, pp. 622-634.

Jiraporn, P., DaDalt, P. (2009), "Does founding family control affect earnings management?" Applied Economics Letters, Vol.16, pp. 113-119.

Jiraporn, P., Kim, Y., Davidson, W., Singh, M. (2006), "Corporate governance, shareholders rights, and firm diversification: An empirical analysis." Journal of Banking and Finance, Vol.30, pp. 947-963.

Kale, J., Reis, E., Venkateswaran, A. (2009), "Rank order tournament and incentive alignment: the effect on firm performance." Journal of Finance, Vol.64, pp. 14791512.

Lang, L., Stulz, R. (1994), “Tobin's Q, corporate diversification and firm performance.” Journal of Political economy, no. 102, pp. 1248-1280.

Lazer, E. (1989), "Pay inequality and industrial politics.” Journal of Political Economy, no. 97, pp. 561-580.

Lazer, E., Rosen, S. (1981), "Rank-order tournaments as optimum labour contracts." Journal of Political Economy, no. 89, pp. 841-864.

Lee, K., Lev, B., Yeo, Hian Heng Yeo, G. (2008), "Executive pay dispersion, corporate governance, and firm performance." Review of Quantitative Finance and Accounting, no. 30, pp. 315-338.

Levine, R. (1991), “Stock markets, growth, and tax policy.” Journal of Finance, Vol.46, no. 4, pp. 1445-1465.

Main, B., Bruce, A, Buck, T. (1996), "Total Board Remuneration and Company Performance.” Economic Journal, Vol.106, no. 439, pp. 1627-1644. 
McNulty, T., Florackis, C.,Ormrod, O. (2013), "Board of directors and financial risk during the credit crisis." Corporate Governance: An International Review, Vol. 21, pp.58-78.

Mehran, H. (1995), "Executive compensation structure, ownership, and firm performance." Journal of Financial Economics, Vol.38, no. 2, pp.163-184.

Milgrom P., Roberts, J. (1992), Economics, Organization and Management. Prentice Hall.

Milgrom, P., Roberts, J. (1988), "An economic approach to influence activities in organisations." American Journal of Sociaology, Vol.94, pp. 154-159.

Morck, R., Shleifer, A., Vishny, R. (1988), "Management ownership and market valuation: An empirical analysis.” Journal of Financial Economics, Vol.20, pp. 293-315.

Murphy, K., Zabojnik, J. (2007), "Managerial capital and the market for CEOs.” working paper, University of Southern California.

Ozerturk, S.(2005) "Board independence and CEO pay.” Economics Letters, Vol.88, pp. 260265.

Pearce II, J., Zahra, S. (1992), "Board composition from a strategic contingency perspective." Journal of Management Studies, Vol. 29, pp. 411-438.

Rankin, F., Sayre, T. (2011), "Responses to risk in tournaments." Accounting Organization and Society, Vol.36, pp. 53-62.

Rosen, S. , (1986), "Prizes and incentives in elimination tournaments." American Economic Review, Vol.76, pp. 701-715.

Section 79, "Members' approval of directors' remuneration policy". Enterprise and Regulatory Reform Act 2013.

Shaw, M., E. (1932), "A comparison of individual and small groups in the rational solution of complex problems.” American Journal of Psychology, Vol.44, pp. 491-498.

Shivdasani, A., Yermack, D. (1999), "CEO involvement in the selection of new board members: An empirical analysis.” Journal of Finance, Vol.54, pp. 1829-1853.

Siegel, P.A., Hambrick, D.C. (2005), "Pay Disparities Within Top Management Groups: Evidence of Harmful Effects on Performance of High-Technology Firms." Organization Science, Vol.16, pp. 259-274.

The UK Corporate Governance Code. Financial Reporting Council, 2010.

Toms, S., Wright, M. (2005), "Divergence and convergence within Anglo-American Corporate Systems: Evidence from US and UK, 1950-2000.” Business History 47, no. 2, pp. 267-295.

Van den Assem, M., van Dolder, D., Thaler, R. (2012), "Split or steal? Cooperative behaviour when the stakes are large." Management Science, Vol.58, no. 1, pp. 2-20.

Van den Berghe L., Levrau A. (2004), "Evaluating boards of directors: what constitutres a good corporate board?" Corporate Governance: An International Review, Vol.12, no. 4, pp. 461-478. 
Yermack, D. (1996), "Higher market valuation of companies with a small board of directors." Journal of Financial Economics, Vol.40, pp. 185-211.

Zahra, S., Pearce, J. (1989), "Boards of directors and corporate financial performance: A review and integrative model.” Journal of Management, Vol.15, pp. 291-334.

Zalewska, A. (2014 b), "Challenges of corporate governance: Twenty years after Cadbury, ten years after Sarbanes-Oxley." Journal of Empirical Finance, no. 27, pp.1-9.

Zalewska, A. (2014 a), "Gentlemen do not talk about money: Remuneration dispersion and performance of British firms.” Journal of Empirical Finance, no.27, pp. 40-57. 


\section{Table 1}

\section{Variable Definitions}

The data variables refer to the corresponding compensation and corporate governance variable identifiers in the BoardEx annual database and to the corresponding performance and firm characteristics variables identifiers in the Tomson Datastream database.

Variable Definition

\section{Compensation}

CEO pay slice (CPS)

CEO pay slice (CPS),

3 directors

$\underline{5}$

Corporate Governance

Board busyness

Board composition

Board size

CEO tenure

Duality

CEO outsider

Performance measure

Tobin's $Q$

\section{F5irm characteristics}

Size

Leverage

Capital expenditures

Company age
The fraction of the total compensation to the group of minimum top-two and maximum top-five executives, including CEO that is received by the CEO.

The fraction of the total compensation to the group of minimum top-two and maximum top-three executives, including CEO that is received by the CEO.

The proportion of busy directors at the board level. Busy directors are defined as directors holding three or more directorships, including the "home" company, in the public companies at the same time.

The proportion of executive directors on the board. Total number of supervisory directors divided by the total number of all directors on the board.

The natural logarithm of the total number of all directors on the board.

The number of years directors have served on the board

Indicator variable: equals one if CEO and Chairman is the same person

CEO Outsider is a dummy equal to one, if CEO was working at the firm for less than one year before becoming CEO.

(Book value of assets - book value of common equity - balance sheet differed taxes + market value of equity)/book value of total assets: (WC02999WC03501 - WC03263 + MV)/WC02999

Natural logarithm of market value: $\operatorname{Ln}(M V)$

Total debt/total assets WC03255/ WC02999

Capital expenditures/ total assets: WC04601/ WC02999

Number of years since company's information is available on Thomson Datastream: BDATE 


\section{Table 2}

\section{Calculation of CPS variables}

This is an example calculation for our measures of CEO pay slice (CPS) using BoardEx database data for the AEGIS GROUP PLC (ISIN GB00B4JV1B90) for the year 1997. Total compensation is a total compensation including salary, bonuses, and equity-based compensation per executive director. The Rank is an executives' rank by total compensation. The proportion of CEO compensation to the total compensation of total five executives including CEO (CPS) is the total compensation of CEO to the sum of total compensations of top five executives..

\begin{tabular}{lcc}
\hline Director & Rank & Total Compensation \\
\hline Sir Crispin Henry Davis (CEO) & 1 & 971 \\
Kai Hiemstra & 2 & 793 \\
Eryck Rebbouh & 3 & 483 \\
Bruno Kemoun & 4 & 476 \\
Colin Richard Day & 5 & 432 \\
Raymond (Ray) F Kelly & 6 & 341 \\
& & \\
& & 3,155 \\
Total Compensation of top five executives & & 971 \\
Tot5al CEO Compensation & & $971 / 3,155=0.3078$ \\
CPS & & \\
\hline
\end{tabular}

\section{Table 3}

\section{Calculation of Board Busyness variables}

This is an example calculation for our measures of director busyness using BoardEx database data for the SAFEWAY PLC (ISIN GB0000492412) for the year 1997. Total number of directorships counts the number of directorships (total number of current quoted boards including the "home" company) held by all directors serving on the board. Directorships per director are estimated as the total number of directorships held by the directors of the board divided by board size. The proportion of busy directors (Board Busyness) is the number of directors holding three or more board seats divided by board size.

\begin{tabular}{ll}
\hline Director & Total Directorships \\
\hline Colin Deverell Smith & 1 \\
David Gordon Webster & 3 \\
Gordon Wotherspoon & 1 \\
Patricia (Pat) Anne O'Driscoll & 1 \\
Robert George Charters & 1 \\
Simon Timothy Laffin & 4 \\
Sir Alistair Grant & 4 \\
Doctor Neville Clifford Bain & 4 \\
Jul5ia Ann Burdus & 2 \\
Michael John Allen & \\
Total Directorships & 22 \\
Directorships per Director & $22 / 10=2.2$ \\
Proportion with three or more directorships & $4 / 10=0.4(40 \%)$ \\
\hline
\end{tabular}




\section{Table 4}

Summary Statistics

This table presents summary statistics for the sample of 7660 firm-year observations for years from 1997 to 2010, excluding financial firms. All variables are winzorized to the 1st /99th percentiles. All variable d5efinitions are in the Table 1.

Mean Minimum Maximum Observations

Panel A: Performance Measure

Tobin's Q

2.55

$0.00 \quad 20.00$

7649

Panel B: Compensation/Director/Board characteristics

CPS

Board composition

$\begin{array}{llll}0.45 & 0.00 & 1.00 & 7028\end{array}$

Board busyness

0.48

0.20

$0.80 \quad 7649$

Board size

0.17

0.00

$0.67 \quad 7649$

Board duality

1.90

1.10

$2.64 \quad 7649$

CEO tenure

0.09

$1.00 \quad 7649$

CEO outsider

4.44

0.00

$24.40 \quad 7649$

0.58

0.00

1.00

7649

Panel C: Firm characteristics

Size

Company Age

Capex/Total Assets

Leverage

$\begin{array}{rrrr}4.36 & -0.22 & 9.83 & 7576 \\ 13.78 & 0.34 & 45.03 & 7579 \\ 0.05 & 0.00 & 0.34 & 7631 \\ 0.18 & 0.00 & 0.95 & 7648\end{array}$




\section{Table 5}

Descriptive statistics on CEO pay slice (CPS) compensation

This table presents descriptive statistics (mean, median, maximum and minimum CPS for our sample firms over the period 1997-2010.

\begin{tabular}{|c|c|c|c|c|c|c|c|c|c|c|c|c|c|c|c|c|c|}
\hline \multicolumn{18}{|l|}{ CPS Descriptive Statistics } \\
\hline \multicolumn{18}{|c|}{$\underline{\text { YEAR }}$} \\
\hline & 1997 & 1998 & 1999 & 2000 & 2001 & 2002 & 2003 & 2004 & 2005 & 2006 & 2007 & 2008 & 2009 & 2010 & $\begin{array}{r}\text { Before SoP } \\
(1997 \\
-2002) \\
\end{array}$ & $\begin{array}{r}\text { After SoP } \\
(2003 \\
-2010) \\
\end{array}$ & $\begin{array}{l}t \text {-stat } \\
(p-v a l)\end{array}$ \\
\hline Mean & 0.32 & 0.36 & 0.38 & 0.40 & 0.40 & 0.42 & 0.43 & 0.44 & 0.45 & 0.46 & 0.48 & 0.48 & 0.48 & 0.50 & 0.40 & 0.47 & \\
\hline Median & 0.31 & 0.34 & 0.36 & 0.37 & 0.37 & 0.39 & 0.41 & 0.42 & 0.43 & 0.44 & 0.47 & 0.47 & 0.50 & 0.50 & 0.37 & 0.46 & \\
\hline Maximum & 0.87 & 0.87 & 0.93 & 0.95 & 1.00 & 1.00 & 1.00 & 1.00 & 1.00 & 1.00 & 1.00 & 1.00 & 1.00 & 1.00 & 1.00 & 1.00 & \\
\hline Minimum & 0.00 & 0.00 & 0.00 & 0.00 & 0.00 & 0.00 & 0.00 & 0.00 & 0.00 & 0.00 & 0.00 & 0.00 & 0.00 & 0.00 & 0.00 & 0.00 & \\
\hline Observations & 37 & 50 & 230 & 351 & 440 & 494 & 560 & 641 & 733 & 819 & 769 & 674 & 612 & 618 & 1602 & 5426 & \\
\hline $\begin{array}{l}\text { Difference of CPS means } \\
\text { (before and after SoP) }\end{array}$ & & & & & & & & & & & & & & & & & $\begin{array}{r}12.03 \\
(0.00) \\
\end{array}$ \\
\hline
\end{tabular}




\section{Table 6}

\section{Firm characteristics by CPS quartiles}

This table presents univariate comparison of means and medians of measures of corporate governance and firm characteristics of 7649 firm years from the 1997-2010 sample of UK-based publicly traded firms, excluding financial firms. The director and board data is from the BoardEx database, firm data is from Tomson Datastream. CEO pay slice (CPS) is the fraction of total compensation to the group of minimum top-two and maximum top-five executive directors including CEO that is received by CEO. Other variables definitions are in the Table 1. The table displays the means and medians (in parentheses) of various director, board, and firm characteristics for first, second, third, and fourth quartiles of CPS. The $t$-statistics is for a difference of means test from the first to the forth quartile of CPS. Each quartile contains approximately 1780 firm -years. *, **, and *** indicate statistical significance at the $10 \%, 5 \%$, and $1 \%$, respectively.

\begin{tabular}{|c|c|c|c|c|c|}
\hline & $\begin{array}{l}\text { First } \\
\text { quartile }\end{array}$ & $\begin{array}{l}\text { Second } \\
\text { quartile }\end{array}$ & $\begin{array}{l}\text { Third } \\
\text { quartile }\end{array}$ & $\begin{array}{l}\text { Fourth } \\
\text { quartile }\end{array}$ & $\begin{array}{l}t \text {-statistic } \\
(p \text {-value })\end{array}$ \\
\hline $\begin{array}{l}\text { CPS characteristics } \\
\text { CPS range }\end{array}$ & 0.00 to 0.0 .32 & 0.32 to 0.44 & 0.44 to 0.0 .58 & 0.58 to 1.00 & \\
\hline CPS & $\begin{array}{c}0.22 \\
(0.25)\end{array}$ & $\begin{array}{c}0.37 \\
(0.37)\end{array}$ & $\begin{array}{c}0.50 \\
(0.50)\end{array}$ & $\begin{array}{c}0.70 \\
(0.65)\end{array}$ & $\begin{array}{c}127.94 * * * \\
(0.000)\end{array}$ \\
\hline CPS, 3 directors & $\begin{array}{c}0.22 \\
(0.30)\end{array}$ & $\begin{array}{c}0.42 \\
(0.43)\end{array}$ & $\begin{array}{c}0.52 \\
(0.52)\end{array}$ & $\begin{array}{c}0.70 \\
(0.66)\end{array}$ & $\begin{array}{c}104.64 * * * \\
(0.000)\end{array}$ \\
\hline \multicolumn{6}{|l|}{ Performance } \\
\hline Tobin's Q & $\begin{array}{l}2.55 \\
(1.51)\end{array}$ & $\begin{array}{c}2.49 \\
(1.50)\end{array}$ & $\begin{array}{c}2.41 \\
(1.47)\end{array}$ & $\begin{array}{c}2.47 \\
(1.50)\end{array}$ & $\begin{array}{l}-0.72 * * * \\
(0.469)\end{array}$ \\
\hline \multicolumn{6}{|l|}{$\begin{array}{l}\text { Director/board } \\
\text { characteristics }\end{array}$} \\
\hline Board busyness & $\begin{array}{l}0.15 \\
(0.13)\end{array}$ & $\begin{array}{c}0.16 \\
(0.14)\end{array}$ & $\begin{array}{l}0.18 \\
(0.17)\end{array}$ & $\begin{array}{c}0.19 \\
(0.17)\end{array}$ & $\begin{array}{l}7.48 * * * \\
(0.000)\end{array}$ \\
\hline Board composition & $\begin{array}{c}0.56 \\
(0.57)\end{array}$ & $\begin{array}{c}0.51 \\
(0.50)\end{array}$ & $\begin{array}{c}0.45 \\
(0.43)\end{array}$ & $\begin{array}{c}0.39 \\
(0.40)\end{array}$ & $\begin{array}{c}-41.00 * * * \\
(0.075)\end{array}$ \\
\hline Board size & $\begin{array}{c}8.00 \\
(8.00)\end{array}$ & $\begin{array}{c}7.62 \\
(7.00)\end{array}$ & $\begin{array}{c}6.69 \\
(6.00)\end{array}$ & $\begin{array}{l}6.25 \\
(6.00)\end{array}$ & $\begin{array}{c}-23.67 * * * \\
(0.000)\end{array}$ \\
\hline Duality & $\begin{array}{c}0.12 \\
(0.00)\end{array}$ & $\begin{array}{c}0.09 \\
(0.00)\end{array}$ & $\begin{array}{c}0.07 \\
(0.00)\end{array}$ & $\begin{array}{c}0.06 \\
(0.00)\end{array}$ & $\begin{array}{l}-6.39 * * * \\
(0.000)\end{array}$ \\
\hline CEO tenure & $\begin{array}{c}4.44 \\
(2.90)\end{array}$ & $\begin{array}{c}4.94 \\
(3.30)\end{array}$ & $\begin{array}{c}4.58 \\
(2.90)\end{array}$ & $\begin{array}{c}3.91 \\
(2.80)\end{array}$ & $\begin{array}{l}-3.43 * * * \\
(0.001)\end{array}$ \\
\hline CEO outsider & $\begin{array}{c}0.49 \\
(0.00)\end{array}$ & $\begin{array}{c}0.52 \\
(1.00)\end{array}$ & $\begin{array}{c}0.59 \\
(1.00)\end{array}$ & $\begin{array}{c}0.65 \\
(1.00)\end{array}$ & $\begin{array}{l}8.74 * * * \\
(0.000)\end{array}$ \\
\hline \multicolumn{6}{|l|}{ Firm characteristics } \\
\hline Size & $\begin{array}{c}4.60 \\
(4.50)\end{array}$ & $\begin{array}{c}4.83 \\
(4.76)\end{array}$ & $\begin{array}{c}4.33 \\
(4.14)\end{array}$ & $\begin{array}{c}4.28 \\
(4.13)\end{array}$ & $\begin{array}{l}-4.04 * * * \\
(0.000)\end{array}$ \\
\hline Company age & $\begin{array}{l}13.75 \\
(8.69)\end{array}$ & $\begin{array}{l}14.36 \\
(9.82)\end{array}$ & $\begin{array}{l}14.27 \\
(9.46)\end{array}$ & $\begin{array}{l}14.87 \\
(8.65)\end{array}$ & $\begin{array}{c}2.41 * * \\
(0.016)\end{array}$ \\
\hline Capex & $\begin{array}{c}0.05 \\
(0.03)\end{array}$ & $\begin{array}{c}0.05 \\
(0.03)\end{array}$ & $\begin{array}{c}0.05 \\
(0.03)\end{array}$ & $\begin{array}{c}0.04 \\
(0.03)\end{array}$ & $\begin{array}{l}-5.11 * * * \\
(0.000)\end{array}$ \\
\hline Leverage & $\begin{array}{c}0.17 \\
(0.13) \\
\end{array}$ & $\begin{array}{c}0.18 \\
(0.14)\end{array}$ & $\begin{array}{c}0.18 \\
(0.14) \\
\end{array}$ & $\begin{array}{c}0.18 \\
(0.13) \\
\end{array}$ & $\begin{array}{l}1.62 \\
(0.1063)\end{array}$ \\
\hline
\end{tabular}




\section{Table 7}

\section{CEO Pay Slice (CPS) and Firm Performance}

This table reports results from an analysis of corporate performance measured by Tobin's Q in our sample of firms from 1997 to 2010. Panel A shows the regression results obtained by using fixed effects models with year dummy variables (not shown) and $t$-statistic based on White's standard errors. Panel B shows the regression results obtained by using fixed effects models with year dummy variables (not shown) and $t$-statistics based on the robust standard errors clustered by industry (we use FTAG3 index as an industry identifier). Panel C shows the regression results obtained by using fixed effects models with $t$-statistics based on Driscoll-Kraay (1998) robust standard errors. The dependent variable is Tobin's Q. CPS is the ratio of CEO total compensation to the sum of maximum top five executives' total compensation and is expressed as decimals. CPS 3 directors is the ratio of CEO total compensation to the sum of maximum top three executives' total compensation and is expressed as decimals. CPS adjusted is industry-adjusted CPS. The industry adjustment is made by subtracting industry mean CPS (at the same FTAG3 level) from firm CPS in the same year. All other variable definitions are in Appendix 1. Standard errors are in parentheses beneath each coefficient estimate. $*$, **, and $* * *$ indicate statistical significance at the $10 \%, 5 \%$, and $1 \%$, respectively.

\begin{tabular}{|c|c|c|c|}
\hline \multicolumn{4}{|c|}{ Panel A: Fixed effects model with White's corrected standard errors } \\
\hline & Model 1 & Model 2 & Model 3 \\
\hline CEO Pay Slice (CPS) & $\begin{array}{l}-0.6182 * * * \\
(0.2052)\end{array}$ & & \\
\hline CPS adjusted & & $\begin{array}{l}-0.6533 * * * \\
(0.2043)\end{array}$ & \\
\hline CPS, 3 directors & & & $\begin{array}{l}-0.5308 * * * \\
(0.1780)\end{array}$ \\
\hline Board busyness & $\begin{array}{l}-0.4887 \\
(0.2758)\end{array}$ & $\begin{array}{l}-0.4890 \\
(0.2758)\end{array}$ & $\begin{array}{l}-0.5139 \\
(0.2770)\end{array}$ \\
\hline Board composition & $\begin{array}{l}-0.0740 \\
(0.3934)\end{array}$ & $\begin{array}{l}-0.0816 \\
(0.3914)\end{array}$ & $\begin{array}{l}-0.0601 \\
(0.3826)\end{array}$ \\
\hline Board size & $\begin{array}{l}-1.6531 * * * \\
(0.1879)\end{array}$ & $\begin{array}{l}-1.6562 * * * \\
(0.1871)\end{array}$ & $\begin{array}{l}-1.5946 * * * \\
(0.1839)\end{array}$ \\
\hline Duality & $\begin{array}{l}-0.1126 \\
(0.1603)\end{array}$ & $\begin{array}{l}-0.1131 \\
(0.1603)\end{array}$ & $\begin{array}{l}-0.1168 \\
(0.1613)\end{array}$ \\
\hline CEO tenure & $\begin{array}{l}-0.0102 \\
(0.0098)\end{array}$ & $\begin{array}{l}-0.0103 \\
(0.0098)\end{array}$ & $\begin{array}{l}-0.0090 \\
(0.0010)\end{array}$ \\
\hline CEO outsider & $\begin{array}{c}0.1036 \\
(0.0928)\end{array}$ & $\begin{array}{c}0.1032 \\
(0.0928)\end{array}$ & $\begin{array}{c}0.0923 \\
(0.0933)\end{array}$ \\
\hline Size & $\begin{array}{l}1.0090 * * * \\
(0.0422)\end{array}$ & $\begin{array}{l}1.0090 * * * \\
(0.0422)\end{array}$ & $\begin{array}{l}1.0200 * * * \\
(0.0424)\end{array}$ \\
\hline Company age & $\begin{array}{l}-0.1729 \\
(0.3178)\end{array}$ & $\begin{array}{l}-0.1647 \\
(0.3178)\end{array}$ & $\begin{array}{l}-0.2059 \\
(0.3187)\end{array}$ \\
\hline Capex & $\begin{array}{l}2.3249 * * * \\
(0.6901)\end{array}$ & $\begin{array}{l}1.3160 * * * \\
(0.6901)\end{array}$ & $\begin{array}{l}2.4900 * * * \\
(0.6922)\end{array}$ \\
\hline Leverage & $\begin{array}{l}1.6539 * * * \\
(0.2558)\end{array}$ & $\begin{array}{l}1.1655^{* * *} \\
(0.2526)\end{array}$ & $\begin{array}{l}1.7047 * * * \\
(0.2565)\end{array}$ \\
\hline Constant & $\begin{array}{c}3.4210 \\
(2.0519) \\
\end{array}$ & $\begin{array}{c}3.4210 \\
(2.0048) \\
\end{array}$ & $\begin{array}{c}3.3691 \\
(2.0319) \\
\end{array}$ \\
\hline Year dummy & Yes & Yes & Yes \\
\hline $\mathrm{R}^{2}$ & 0.16 & 0.16 & 0.16 \\
\hline Number of observations & 6959 & 6959 & 6959 \\
\hline
\end{tabular}


Table 7 (cont)

\begin{tabular}{|c|c|c|c|}
\hline \multicolumn{4}{|c|}{ Panel B: Fixed effects model with robust standard errors clustered by industry FTAG3 code } \\
\hline & Model 1 & Model 2 & Model 3 \\
\hline CEO Pay Slice (CPS) & $\begin{array}{l}-0.6182 * * * \\
(0.2161)\end{array}$ & & \\
\hline CPS adjusted & & $\begin{array}{l}-0.6533 * * * \\
(0.2043)\end{array}$ & \\
\hline CPS, 3 directors & & & $\begin{array}{l}-0.5308 * * * \\
(0.1783)\end{array}$ \\
\hline Board busyness & $\begin{array}{l}-0.4887 \\
(0.4485)\end{array}$ & $\begin{array}{l}-0.4890 \\
(0.24472)\end{array}$ & $\begin{array}{l}-0.5139 \\
(0.4523)\end{array}$ \\
\hline Board composition & $\begin{array}{l}-0.0740 \\
(0.4060)\end{array}$ & $\begin{array}{l}-0.0103 \\
(0.0116)\end{array}$ & $\begin{array}{l}-0.0601 \\
(0.3997)\end{array}$ \\
\hline Board size & $\begin{array}{l}-1.6531 * * * \\
(0.3478)\end{array}$ & $\begin{array}{l}-1.6562 * * * \\
(0.3522)\end{array}$ & $\begin{array}{l}-1.5946 * * * \\
(0.3427)\end{array}$ \\
\hline Duality & $\begin{array}{l}-0.1126 \\
(0.2364)\end{array}$ & $\begin{array}{l}-0.1131 \\
(0.2371)\end{array}$ & $\begin{array}{l}-0.1168 \\
(0.2359)\end{array}$ \\
\hline CEO tenure & $\begin{array}{l}-0.0102 \\
(0.0116)\end{array}$ & $\begin{array}{l}-0.0103 \\
(0.0116)\end{array}$ & $\begin{array}{l}-0.0090 \\
(0.0117)\end{array}$ \\
\hline CEO outsider & $\begin{array}{c}0.1036 \\
(0.1305)\end{array}$ & $\begin{array}{c}0.1032 \\
(0.1307)\end{array}$ & $\begin{array}{c}0.0923 \\
(0.1260)\end{array}$ \\
\hline Size & $\begin{array}{l}1.0090 * * * \\
(0.1361)\end{array}$ & $\begin{array}{l}1.0090 * * * \\
(0.1363)\end{array}$ & $\begin{array}{l}1.0200 * * * \\
(0.1352)\end{array}$ \\
\hline Company age & $\begin{array}{l}-0.1729 \\
(0.2990)\end{array}$ & $\begin{array}{l}-0.1647 \\
(0.2942)\end{array}$ & $\begin{array}{l}-0.2059 \\
(0.3083)\end{array}$ \\
\hline Capex & $\begin{array}{c}2.3249 \\
(1.4852)\end{array}$ & $\begin{array}{c}2.3160 \\
(1.4854)\end{array}$ & $\begin{array}{c}2.4900 \\
(1.4715)\end{array}$ \\
\hline Leverage & $\begin{array}{c}1.6539 * \\
(0.8179)\end{array}$ & $\begin{array}{c}1.6582 * \\
(0.8164)\end{array}$ & $\begin{array}{l}1.7047 * \\
(0.8095)\end{array}$ \\
\hline Constant & $\begin{array}{c}3.4210 \\
(2.0048)\end{array}$ & $\begin{array}{c}3.1849 \\
(1.9676)\end{array}$ & $\begin{array}{c}3.3691 \\
(2.0701)\end{array}$ \\
\hline Year dummy & Yes & Yes & Yes \\
\hline $\mathrm{R}^{2}$ & 0.16 & 0.16 & 0.16 \\
\hline Number of observations & 6959 & 6959 & 6959 \\
\hline
\end{tabular}


Table 7 (cont)

Panel C: Fixed effects model with Driscoll-Kraay standard errors

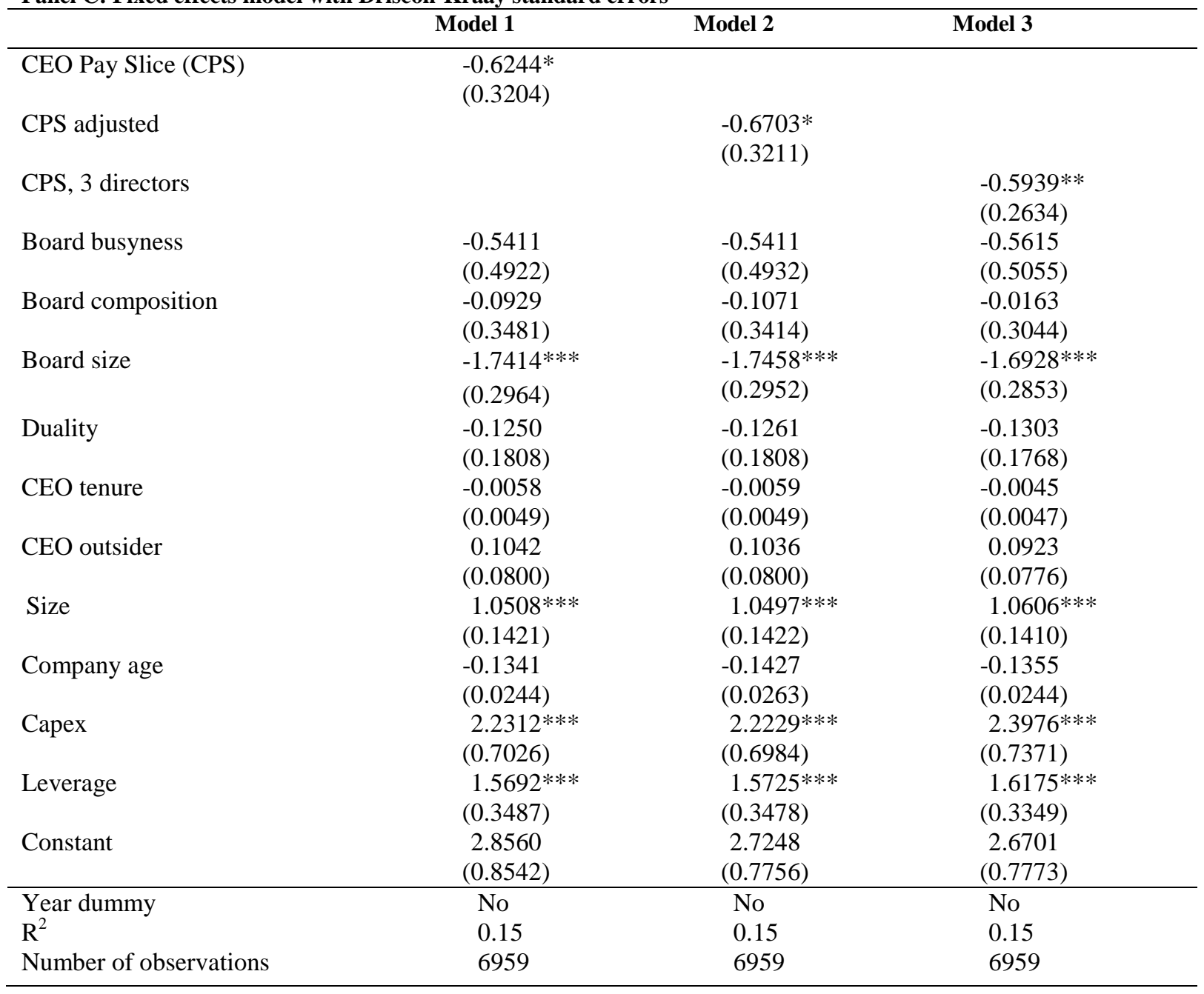

